\title{
Cinderella and Pandora's box - Autoethnographic Reflections on My Early Career Research Trajectory between Australia and China
}

\author{
JINJIN LU
}

\begin{abstract}
In the last decade, the world has witnessed significant changes in terms of economic, educational, and cultural development both inside and outside China, creating valuable opportunities to better understand the cultural stereotypes Asians and Westerners have regarding each other. In this paper, I examine my immigrant experiences as a female, bilingual early-career researcher in multilingual and multicultural environments and my subsequent re-entry into China to work as a leading researcher within a span of ten years. My series of auto-ethnographic dialogues between a cast of characters, in which they recall experiences, perceptions, and emotions, provides readers with ample opportunities to actively respond to the text. Through this autoethnographic memoir and performance, I hope to contribute to new directions for narrative research in intercultural contexts.
\end{abstract}

Keywords: auto-ethnography; cultural identities; Chinese education; narrative inquiry

\section{Inspiration}

\section{LOVE}

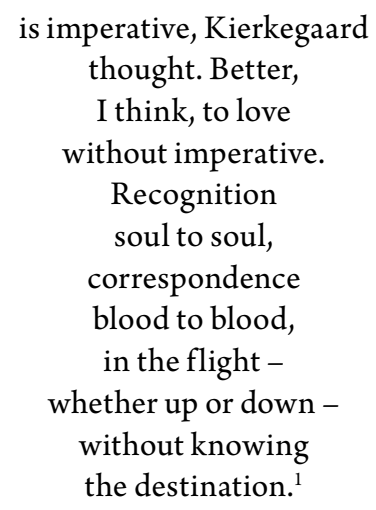

1 English translation by Harvey L. Hix. 
This poem, titled 'Love', written by Professor Jüri Talvet, has been translated into 80 languages (Talvet 2019). I never imagined that I would get the opportunity to have a face-to-face discussion with the writer about my understanding of it. In March 2019, I was invited to read the Chinese version of this poem at a seminar held at my university. Excitement, joy, passion, and nervousness were evident in my tone and voice. While reading the poem, loving memories played in my mind like a film.

I was born into a middle-class family living at the source of the Yangtze River in the centre of China. My maternal grandfather, who had been heavily influenced by the Chinese cultural revolution, passed away before I was born. My grandmother, my parents, and I lived in a shabby apartment for many years. During the day, my grandmother, who had been a housewife for much of her life, looked after me, and, in the evening, she was very patient when reading stories along with me. She told my parents that I should start reading books about Chinese literature at an early age because she believed that it could broaden my perspective. My grandmother showed her love and care for me throughout my childhood with many gentle hugs and morning cheek-kisses. Although my parents did not have much money, my grandmother always asked my parents to save money to pay for my future educational expenses. Although she never received a formal education herself, she wished for me to travel abroad to continue my education overseas. My family's love and hard work were very similar to what Jüri Talvet described in his poem when showing affection to his little daughter. On the one hand, he hoped that his little angel would have time to enjoy her childhood. On the other hand, he wished that she would practise her musical instrument more diligently. The double-edged sword of parental love often consists of both familial expectations and the desire to respect a child's will.

One of my favourite stories from my book list was the Chinese version of 'Cinderella'. Although this story is a fairy tale, it has given me courage and strength. My paternal grandfather always looked down on girls. When I was little, I often exhibited jealousy toward the boys in my extended family. Although it has been difficult to realise my dreams, the story has sparked my creativity and given me hope in life. Surrounded by love throughout my childhood, I was treated as the core of my family. Due to the constraints imposed by the 'one-child policy' in China, I felt that I had to study, behave, and do as my family expected. Sometimes, being overburdened with love pushed me to feel lost during my childhood. After I entered primary school, I felt that I was under intense pressure to succeed in my studies. I did seemingly endless homework during the week and was enrolled in other activities on the 
weekends, such as drawing and music classes and sports. Sometimes, I felt that I was like a compressed biscuit, but no matter how much I achieved, my family would not be satisfied because they subscribed to Chairman Mao's attitude of 'Humility makes progress.' During my school years, I felt like a pigeon that wished to leave its cage one day. I wished that I could open a Pandora's box and realise my dreams. I saw my dreams partially realised after I immigrated to Australia and worked as an academic staff member there.

\section{Theoretical Concepts}

In the following section, I review studies of immigrants' cultural identities, cultural transfusions, and hybrid spaces. As a first-generation immigrant who completed higher education in the West, the way I was brought up and my early learning trajectory have had a significant influence on my life in Australia. I use my diaries to provide a window through which both I and others from a similar cultural background can explore immigrants' cultural identities. My shifting spaces have brought me many opportunities and challenges, and they have also inspired me to reflect on myself and reconstruct my identity.

Immigrants' Cultural Identities. Cultural identity is related to a person's affiliation with his/her ethnic group of origin and national identity. Self-definition and understanding of one's cultural identity are essential to facilitating social communication and developing a sense of belonging within a social context. Stella Ting-Toomey (1999: 30) defines cultural identity as the emotional significance that we attach to our sense of belonging or affiliation with the larger culture'. Attempting to integrate oneself into a new culture in a host country brings many challenges, such as language barriers, culture shock, and issues with social interactions. Without a good understanding of the surrounding culture, identity construction is difficult, since 'culture is both a function and a source of identity' (Ashcroft \& Ahluwalia 1999: 90).

For immigrants, however, cultural affiliations might be more complex and difficult to reconcile with their identity-construction processes. Immigrants may come from a monolingual social context and move to a multicultural and multilingual nation or vice versa. Hence, the way they perceive their identity is believed to follow a 'bipolar' model (Eisenstadt 1955). That is, immigrants' learning in their country of origin and life experiences gained before immigration tend to deeply influence their ways of perceiving and constructing their cultural identities in their new countries. In this regard, immigrants tend 
to experience this process in a 'push and pull' way, weakening their original cultural identities to adjust to the new environment while attempting to behave as others do to be accepted in the receiving country. Tartakovsky (2013) believes that, in the process of being 'pushed and pulled', people find it very difficult to have simultaneous affiliations with two cultures. Sometimes, immigrants may experience a lack of support from members of their original ethnic group or others may even prevent them from adjusting to the new context. In this case, personal, familial, and social supports are essential for assisting immigrants in integrating into the new country.

Cultural Transfusion. Immigrants often feel challenged in their new lives when moving to a new country. Cultural transfusion is viewed according to the following perspective: 'the same way as in the blood transfusion, new ideas or elements, taken from donor cultures are being incorporated into old systems of beliefs, so that the recipient culture regains its life and vitality' (Petkova 2018: 11). Immigrants do not deny their histories, languages, or past experiences during this process. On a positive note, after immigrating, their children are often willing to trace their ancestors' footprints within their original ethnic groups. In this way, when adjusting to the new environment, the existing gaps or inconsistencies in their old belief structures are filled with new ideas (Petkova 2018). In Europe, cultural transfusion is also perceived as 'intercultural trânsfuga' (Vieira \& Trindade 2008: 38). This concept adds a new dimension to the concept of cultural identity. Instead of comparing 'I' with 'others', cultural transfusion accepts immigrants' hybrid creations, and they appear to 'have no problem in travelling back to contexts of their past' (ibid.).

Hybrid Spaces. Hybridity originally referred to 'mixed' blood with abuse (Meredith 1998), but now 'it is celebrated and privileged as a kind of superior cultural intelligence owing to the advantage of in-betweenness, the straddling of two cultures and the consequent ability to negotiate the difference' (Hoogvelt 1997: 158). The concept of hybrid spaces has been developed by Bhabha (1994), who links the conception of hybridity to a third space. Previous studies have highlighted the hybridity in the third spaces that diaspora communities and second-generation immigrants have created in response to their environments (Isik-Ercan 2014; L. K. Wang 2016). Moje et al. (2004: 41) interpreted the third space as a spatial construct that "merges the "first space" of people's home, community, and peer networks with the "second space" of the discourses they encounter in more formalised institutions such as work, church, or school'. Immigrants shift between spaces, and, during this process, 
they are provided with opportunities to reconstruct their identities or even cultivate new ones.

\section{Auto-ethnography as a Research Method}

In the qualitative research studies, autoethnography is a useful research method used to analyse people's lives, a tool that Ellis and Bochner (2000: 739) define as "....an autobiographical genre of writing that displays multiple layers of consciousness, connecting the personal to the cultural”. In the recent years, using auto-ethnography as a research method has been become popular to examine researcher' own cultural identities and communicate cultural nuances to invite readers into various spaces. By using this method, both readers and I (researcher) can obtain a deeper understanding of the uniqueness of Chinese culture and how my identity has shifted between learning and work contexts. I use multiple forms of data to support my auto-ethnographic essay to analyse personal experiences (Creswell 2013; Ellis, Adams \& Bochner 2011). Tensions tend to arise whenever researchers use auto-ethnographic approaches to represent themselves and others. Indeed, Nicholas Holt (2003) asserts:

Writing themselves into their own work as major characters, auto-ethnographers have challenged accepted views about silent authorship, where the researcher's voice is not included in the presentation of findings.

Lydia Turner (2013) claims that auto-ethnographic writing can be used to engender relationships between researchers and participants. Sally Denshire (2014: 832) argues that this writing style resists 'the grain of much academic discourse'. Although auto-ethnographic approaches to qualitative inquiry have not always been widely accepted (Chang 2008), the personal, nuanced insights of auto-ethnographic researchers are now contributing to the literature via an increasing number of auto-ethnographic publications in journals such as Life Writing, Autobiography and Reflective Practice.

Delving into individuals' stories offers many opportunities for researchers to position themselves within larger socio-cultural contexts. Being a female, non-native English speaker and a first-generation Chinese-Australian immigrant who is accustomed to working and living in Westernised contexts, I consider auto-ethnography the most suitable method to 'pursue relationships' through my essay. Using auto-ethnography as a research method can be beneficial to me, as a researcher, by helping me acknowledge the unexamined cultural and social contexts of my experiences (Chang 2008; Ellis 2004; Ellis 
et al. 2011). In her doctoral thesis, for example, Vera Neyman (2011) used autoethnography to examine the teaching experiences and major problems she encountered in an American public school as a native Ukrainian and English teacher. Her study, which sheds light on her academic and professional life, is interwoven with her personal story.

It can be even more difficult for a non-native English-speaking female academic who has shifted between multicultural and multilingual societies and re-entered the motherland to readjust to her country of origin. Bin Ai (2015, 2019) used the same research method to investigate Chinese scholars' pains and gains in an EFL-teaching context when they re-entered China. In his recent auto-ethnographic essay, $\mathrm{Bin} \mathrm{Ai}$ (2009: 661) describes his struggles, challenges, and concerns when returning to a Chinese mainland university:

As a returnee to mainland China, I have often asked myself how I could contribute to my homeland. I cannot make inventions that will change the lives of human beings, nor find a therapy to treat cancer. Yet I believe that I can contribute to my research community after returning by writing about my everyday research experiences in more detail, since they are part of the complex process of my academic (re)construction at Chinese universities.

The following stories, which I recorded in my diary, have been excerpted to serve as the main resources for my auto-ethnographic essay. They were written in English weekly from my early years till now. This type of data has been used widely in previous research studies. For example, Andrew Sparkes (1996: 466) used diary excerpts to help him write, as he believed that 'we shrink the distance between the experiencing subjects and their accounts of lived experience'. The value of diary use has been discussed by Paul Thompson and Mary Chamberlain (1998), who regard keeping personal diaries as a better means of assisting those of lower socio-economic status and women in raising their voices than traditional data-collection methods. More recently, Jinjin Lu (2019) presented diary excerpts to demonstrate her unique cultural identity, which was influenced by Confucianism, in the West. Elizabeth Chaplin (2011) claims that diary excerpts can present intimate, subcultural information that other types of writing cannot when doing auto-ethnography. I believe that these stories from my diary display the cultural nuances of my experience from a unique angle within my auto-ethnographic piece.

\section{Diary Excerpt 1: Humility Makes Progress}

I called my parents early in the morning before I went to work. They knew that it was my first day in my new position and asked me to repeat Chairman 
Mao's slogan, 'Humility makes progress', several times. I was fed up with the slogan, but my parents warned me that it was my first day and that I would be meeting my new colleagues for the first time. By keeping the slogan in mind, I could make a good impression on them. I did not want to explain what I was feeling, as my parents would not have understood how we navigate relationships between colleagues here. I did not want to waste any time so early in the morning, so that I swore to them that I would follow their advice. I hung up the phone quickly and went to the office.

My supervisor, Jane, and I had an appointment to discuss my job responsibilities and goals and assist me in settling into the job quickly. Walking quietly into the office, I summoned all my strength to shake hands with Jane. She asked why my hands were so cold. I hesitated for a few minutes. I did not have any clue how to answer this question. Finally, I told her that I felt cold. Jane looked at me and questioned whether I was playing any sports or doing any exercise on the weekends. This question made me feel even more uneasy, as I did not know whether walking was the type of exercise that she expected me to do. I grabbed a cup of water to hide my nervousness and then answered that I would like to exercise, but currently I only took walks on the weekends. My supervisor suggested that I should join some community sports clubs to find groups of people with common interests and balance my work and personal life by doing activities in my spare time. In our interaction, she talked most of time, and I kept quiet. When my supervisor explained the guidelines for my job, I consistently nodded to show respect. In the meeting, Jane smiled gently and asked me if I understood what she had said. I was told that, if I had any questions, I could raise my concerns so that she and I could feel more comfortable. During the meeting, I wanted to share some ideas about my project with her, but there was a voice in my head telling me not to speak much so that I could avoid making silly mistakes. Finally, I gave up on my idea and accepted what Jane thought. After the meeting, I sat quietly in front of my desk, looking out the window miserably... (6 April, 2015)

I have read this diary excerpt many times while reflecting on my identity in the West. I was born in China and spent a lot of time in my early childhood with my grandmother, a traditional housewife, who did not receive any formal education. Her love for our family had been passed on throughout the generations. In this environment, I could sense deeply that my parents had loved me without receiving any benefit themselves. Consequently, they expected that I would study and work hard to reward them. Even after immigrating to another country, my immigrant cultural identity remained in a state of being 'pushed and pulled' by my family. Although I am physically residing in Australia, I still feel the influence of my parents, my home culture, and the larger culture I am affiliated with every second of my life (Ting-Toomey 
1999). My identity has been significantly influenced by my Chinese parents' love and overprotective nature. Therefore, while talking with my supervisor, I tried not to talk much because I was warned as a child that I might make mistakes if I talked a lot. This is what my parents warned me of, again and again. This kind of parenting style and way of showing love and protection can lead to depression among Chinese people after immigrating (Lim \& Lim 2003). Sometimes, I was very eager to communicate with my parents by sharing both good news and sorrows with them, particularly stories of parties I attended. Unfortunately, our home culture and the topics that they want to discuss with me made me feel uncomfortable; as a consequence, I tried to avoid calling them frequently. This 'pushed and pulled' feeling even extends to my daily communications with my colleagues. I am working with a bunch of colleagues in a 'white' cultural context. In this context, I have been expected to become assimilated into the large cultural environment around me. However, the home culture that I experienced in my early childhood made it a challenge to successfully complete the cultural transfusion to my new home. My case does not reflect what Petkova (2018) believes - that immigrants can be beneficial to both the home culture and the culture of the new environment.

Additionally, I was educated in my early school years by exposure to slogans such as 'Self-reliance and arduous work', 'Humility makes progress', and 'Criticism and self-criticism' (Wu \& Yu 2016). They were imprinted on my mind even after I finished my formal education, and they influenced me in the construction of my identity as a new immigrant in Australia. In my parents' generation, people were strongly encouraged by propaganda to show respect for Chairman Mao. They respected teachers without employing any critical thought. In my case, during my early school years, I was not allowed to talk back to my parents or teachers. Even when I found that teachers made mistakes, I was unable to discuss the issue with my parents. This has been described by Liu (2010), who experienced the Chinese cultural revolution. She believes that freethinkers are currently needed in China, but this kind of mindset is rare in the Chinese context. In my current cultural context, I am expected to behave as an equal to others and be brave enough to express my opinions freely. However, these slogans have restricted me when attempting to express my ideas because my home culture is deeply rooted in my psyche.

\section{Diary Excerpt 2: Guilty for Going Out on Weekends}

My parents required me to have a video call with them, but we ended it on an unpleasant note. I told my parents that I felt guilty when walking past parks on weekends. They felt very surprised and asked me the reason. I told them that I felt very sad when thinking about how my cousins' children had to attend 
various extracurricular classes, such as those in drawing, musical instruments, and handwriting, on weekends while I was watching children riding bikes with their siblings in Australia. I asked my mum, 'Have you ever thought that our Chinese educational system should be reformed because of the destructive competition between parents, children, and schools?' My mum smiled coldly, and, instead of answering me directly, she asked me to explain why I had this crazy idea, as my parents believed that it was normal for children to attend various classes on weekends. I cited data from academic articles and scholarly books to provide them with many examples of the negative influence on children and families when children are driven by their parents to take these sorts of classes. Nevertheless, they insisted that their viewpoint was correct: the Chinese educational system is good, and children feel happy in the environment created by it. Before asking to learn more about my opinions, they asked me, 'Did you grow up in this system, and did you do well?' Furthermore, they asked me if I had a good compulsory education in China and had finally finished my PhD based on how this system had educated me. Suddenly, I lost my words, and I did not know what sort of counterargument to make. (30 November, 2014)

I had these sorts of unpleasant interactions with my parents many times. I understand that my parents are among the millions in China who have always expected their children to be successful in their endeavours. To this end, parents are eager to take their children to various groups and classes, even when they are still little. I love my parents more than anyone else, but our conflicts regarding educational ideology, culture, and politics have never been reconciled across the two hemispheres. I was trained to perform excellently on the Chinese examinations when I was in China. The system relies heavily on written exams. Chinese students must submit to various forms of high-stakes examinations throughout their academic careers, from primary school to higher education. This powerful educational system has been employed in China for thousands of years. The keju of the Han dynasty and gaokao employed after the founding of the PRC are examples of such exams. The keju exams used in ancient times aimed to identify the most intelligent people and place them in positions as government officials. The exams were held at many levels, from the local to the final imperial level, and examinees spent several years competing with others (J. Wang \& Jang 2016). Like the national gaokao, these exams were held every year. Due to the intense nature of the examinations, which last a few days, the gaokao not only puts pressure on students but also their families (X. Yu \& Han 2019). Chinese parents put a lot of effort into helping their children succeed and can feel more pressure than their children to ensure their success on the gaokao. In this context, I feel I should thank my parents for their unlimited 
support of my desire to study overseas, which has helped me greatly in my current research career.

However, as a critical researcher, I must admit that I felt restricted by this kind of pen-and-paper examination-oriented educational system when I was in school. Jinjin $\mathrm{Lu}$ (2018) showed that she felt that she was under a lot of pressure because she had been influenced by Confucian teaching and learning styles. In her essay, she presented her experiences with culture shock when she took advantage of China's 'open door policy' to become an international student in the USA in the $21^{\text {st }}$ century. Similar experiences can be found in the research of returnees to China (Ai 2019; H. Liu 2005; Xu 2018). These scholars have discussed cultural adaption and the challenges that Chinese researchers face when they return to their motherland. These lead them to reconstruct their social ties and cultural and academic identities. In the process of returning to China to work as an academic, I encountered many challenges.

\section{Diary Excerpt 3: Struggling to Be Back}

I argued with my parents again, as they doubted whether I was a normal girl. According to Chinese values, I should have gotten married ten years ago and been happy with having a family. My parents told me that they did not understand why I was unhappy when working with my colleagues in China. The university where I work is a high-ranking one, and I have attained a relatively high academic position compared to my peers. However, I told my parents that the way that they evaluated my research made me crazy. The way that the administrative procedures worked was also terrible. For example, I had spent three hours queuing that day just to get a reimbursement for my train tickets for my research trip in China. Unfortunately, I was told by the financial officer that my train fare could not be reimbursed because I had to hand in a pre-filled form via the office's designated system and then send it to be approved by the dean, director of the research office, and others. When I was back home, I told my parents about my experience that day and I thought that they would understand my frustration, but I was told that 'this was China', where I could not expect much else. I should go along with whatever my colleagues did so that I would be on the same page as they were. I told my parents how easy it was to get research-related trip expenses reimbursed in Australia. I finished my $\mathrm{PhD}$ so I could make contributions to my research field through critical thought. By following others, I did not believe that our society could progress. After hearing these words, my parents believed that I have been completely 'brainwashed' by Western ideas. They urged me to get married quickly and behave 'normally', as others did. (10 November, 2017)

I have been back as a 'Haigui' (Louie 2008) for a few years in mainland China. Though I was regarded as an academic talented overseas Chinese scholar, I 
felt very emotional while reading and selecting these diary stories in the writing. From being a young researcher to a senior academic, my experience reflected the phenomenon that Amy Chua's book titled 'Battle Hymn of the Tiger Mother' described (2011). Although my parents did not finish their postgraduate studies, they placed high expectations on me when I was little. They were not easily satisfied with either my academic performance or my personal choices. After returning to China, the most important discussions between me and my parents were all about me having a family and children. They believed that my career was on the right track, but my personal life was a complete mess. Traditionally, Chinese girls have a family and children by their mid-20s, and my parents worried that I might become a 'leftover' (Y. Yu 2019). Chinese 'leftover' women are those who are still unmarried after the age of 27 (Y. Yu 2019:1). These labels have been widely spread by Chinese media since 2007, and nowadays single women and their parents are pressured by people who call the women 'leftovers' in public. My parents are not an exception to this phenomenon, so I have been pushed very hard to go on many blind dates on weekends. Scholars believe that the construction of the Chinese 'leftover women' myth is a manifestation of a neo-Confucian trend and represents the revival of gender-based inequality (Fincher 2014; You, Yi, \& Chen 2016). The ideology I have formed by living in two contexts, China and Australia, does not bring me any advantage, as I am an 'in-betweener' (Hoogvelt 1997). I cannot help but feel that my cultural transition between two places drags me into another 'space' in which I usually imagine that I am living close to my parents, but the other people around me are like Australians. My experience is similar to what Bin Ai (2019) refers to as an 'imagined space' that he wants to inhabit. This space would not only be more comfortable and safer than reality for Chinese academics but it would provide more freedom and a democratic context in which Chinese returnees from overseas could reconstruct their personal and cultural identities.

\section{Closing Remarks}

In the first part of my article, I focused on my reflections on my bilingual learning trajectory from China to the USA (Lu 2018). In the second half of my auto-ethnographic writing project, I reflect on the trajectory of my early-career research life from China to Australia. Writing this article has provided me with an opportunity to reflect on my experiences as a first-generation Chinese immigrant, female researcher, and Chinese returnee from overseas within a period of ten years. 
In this paper, I used my own story to show how my experiences were enhanced though auto-ethnographic writing, which should encourage members of my audience to reflect on their own experiences of educational and cultural adaption and their connected, underlying cultural associations, utterances, and life experiences in a comparative context. The Pandora's box that was given to me as a gift has been sitting on my desk for a long time. As an adult, I understand that it is just an empty box; however, I often place it on top of my books so that it will remind me of my parents' love and expectations, my own goals, and the dreams of my early childhood.

\author{
Jinjin Lu \\ helen820919@sina.com \\ China University of Geosciences (Wuhan) \\ 388 Lumo Rd, Hongshan \\ Wuhan, Hubei \\ 430074 \\ CHINA
}

\title{
References
}

Ai, B. 2015. Living in-between: A Narrative Inquiry into the Identity Work of a Chinese Student in Australia. - Life Writing, 12(3), 353-368. https://doi.org/10.1 080/14484528.2015.1053028

Ai, B. 2019. Pains and Gains of Working in Chinese Universities: An Academic Returnee's Journey. - Higher Education Research \& Development, 38(4), 661-673. https://doi.org/10.1080/07294360.2019.1590320

Ashcroft, B., \& Ahluwalia, P. 1999. Edward Said: The Paradox of Identity. London: Routledge.

Bhabha, H. 1994. The Location of Culture. London: Routledge.

Chang, H. 2008. Autoethnography as Method. Walnut Creek, C.A.: Left Coast Press.

Chaplin, E. 2011. The Photo Diary as an Autoethnographic Method. - E. Margolis \& L. Pauwels, eds., The SAGE Handbook of Visual Research Methods. London: Sage, 241-262. https://doi.org/10.4135/9781446268278.n13

Chua, A. 2011. Battle Hymn of the Tiger Mother. London: Penguin.

Creswell, J. 2013. Qualitative Inquiry Research Design. $3^{\text {rd }}$ ed. London: Sage.

Denshire, S. 2014. On Auto-ethnography. - Current Sociology Review, 62(6), 831-850. https://doi.org/10.1177/0011392114533339

Eisenstadt, S. N. 1955. The Absorption of Immigrants. Illinois: Free Press.

Ellis, C. 2004. The Ethnographic I: A Methodological Novel about Autoethnography. Walnut Creek, MA: AltaMira Press. 
LU

Ellis, C., Adams, T. E., \& Bochner, A. P. 2011. Autoethnography: An Overview. Forum: Qualitative Social Research, 12(1), 1-18.

Ellis, C., Bochner, A. P. 2000. Autoethnography, Personal Narrative, Reflexivity: Researcher as Subject. - N. K. Denzin \& Y. S. Lincoln, eds., Handbook of Qualitative Research. London: Sage, 733-768.

Fincher, L. H. 2014. Leftover Women: The Resurgence of Gender Inequality in China. London: Zed Books.

Holt, N. 2003. Representation, Legitimation, and Autoethnography: An AutoEthnographic Writing Story. - International Journal of Qualitative Methods, 2(1), 1-22. https://doi.org/10.1177/160940690300200102

Hoogvelt, A. 1997. Globalization and the Postcolonial World: The New Political Economy of Development. Baltimore: The Johns Hopkins University Press.

Isik-Ercan, Z. 2014. Third spaces: Turkish immigrants and their children at the intersection of identity, schooling, and culture. - Diaspora, Indigenous, and Minority Education, 8(3), 127-144. https://doi.org/10.1080/15595692.2014.897 222

Lim, S.-L., \& Lim, B. K. 2003. Parenting Style and Child Outcomes in Chinese and Immigrant Chinese Families-Current Findings and Cross-Cultural Considerations in Conceptualization and Research. - Marriage \& Family Review, 35(3-4), 21-43. https://doi.org/10.1300/J002v35n03_03

Liu, H. 2005. New Migrants and the Revival of Overseas Chinese Nationalism. - Journal of Contemporary China, 14(43), 291-316. https://doi.org/10. $1080 / 10670560500065611$

Louie, K. 2008. Angry Chinamen: Finding Masculinity in Australia and China. Comparative Literature: East \& West, 10(1), 34-39. https://doi.org/10.1080/257 23618.2008.12015585

Lu, J. 2018. Of Roses and Jasmine - Auto-Ethnographic Reflections on My Early Bilingual Life through China's Open-Door Policy. - Reflective Practice, 19(5), 690-706. https://doi.org/10.1080/14623943.2018.1538959

Lu, J. 2019. Confucius Stands on the London Eye - an Auto-ethnographic Study. Ethnography and Education, 14(1), 51-64. https://doi.org/10.1080/17457823.201 7.1387067

Meredith, P. 1998. Hybridity in the Third Space:Rethinking Bi-cultural Politics in Aotearoa/New Zealand. Paper presented at the Te Oru Rangahau Maori Research and Development Conference, New Zealand.

Moje, E. B., Ciechanowski, K. I., Kramer, K., Ellis, L., Carrillo, R., \& Collazo, T. 2004. Working toward Third Space in Content Area Literacy: An Examination of Everyday Funds of Knowledge and Discourse. - Reading Research Quarterly, 39(1), 38-70. https://doi.org/10.1598/RRQ.39.1.4

Neyman, V. L. 2011. Giving My Heart a Voice: Reflection on Self and Others through the Looking Glass of Pedagogy: An Autoethnography. (PhD). Ann Arbor: National-Louis University. Retrieved from http://search.proquest.com/docview/887719405?acco untid $=10344$, available from ProQuest Central, ProQuest Dissertations \& Theses Global. 
Petkova, D. 2018. Death, After-Life and Rebirth: Cultural Transfusion of Ideas. Journal of Narratives and Social Sciences, 2, 8-20.

Sparkes, A. C. 1996. The Fatal Flaw: A Narrative of the Fragile Body-Self. - Qualitative Inquiry, 2(4), 463-494. https://doi.org/10.1177/107780049600200405

Talvet, J. 2019. Critical Essays on World Literature, Comparative Literature and the "Other". Newcastle upon Tyne: Cambridge Scholars Publishing.

Tartakovsky, E. 2013. Cultural Identities of Immigrants: Their Formation in the Pre-migration Period and their Transformation during Adjustment to the Host Country. - E. Tartakovsky, ed., Immigration: Policies, Challenges and Impact. New York: NOVA Science, 231-254.

Thompson, P., Chamberlain, M. 1998. Introduction: Genre and Narrative in Life Stories. - P. Thompson \& M. Chamberlain, eds., Narrative and Genre. London: Routledge, 1-22. https://doi.org/10.4324/9781315125008-1

Ting-Toomey, S. 1999. Communicating across Cultures. New York: Guilford.

Turner, L. 2013. The Evocative Autoethnographic 'I': The Relational Ethics of Writing about Oneself. - N. P. Short, L. Turner, \& A. Grant, eds., Contemporary British Autoethnography. Rotterdam: Sense, 213-229. https://doi.org/10.1007/978-946209-410-9_14

Vieira, R., Trindade, J. 2008. Migration, Culture and Identity in Portugal. - Language and Intercultural Communication, 8(1), 36-49. https://doi.org/10.2167/laic266.0

Wang, J., Jang, W. 2016. Educational Inequality among Chinese Urban Schools: The Business Ethics of Private Schools. - Asia Pacific Business Review, 22(3), 502-515. https://doi.org/10.1080/13602381.2015.1129776

Wang, L. K. 2016. The Benefits of In-betweenness: Return Migration of SecondGeneration Chinese American Professionals to China. - Journal of Ethnic and Migration Studies, 42(12), 1941-1958. https://doi.org/10.1080/136918 3X.2016.1139447

Wu, T.-J., Yu, P.-L. 2016. Media, Environment of Quotations, Cult of Personality: Research Based on People's Liberation Army Daily (1960-1969). - Mass Communication Research, 127, 39-73.

$\mathrm{Xu}, \mathrm{X} .2018$. The Role of Self-Reflection in Facilitating Cross-Cultural Adaptation as Self-Formation - a self-reflective diary approach. - Reflective Practice, 19(6), 832-843. https://doi.org/10.1080/14623943.2018.1539661

You, J., Yi, X., \& Chen, M. 2016. Love, Life, and 'Leftover Ladies' in Urban China. Retrieved from https://mpra.ub.uni-muenchen.de/70494.

Yu, X., \& Han, Y. 2019. How Humble Families Produce “Successful Descendants”Class Advancement from the Perspective of Cultural Capital. - Chinese Education \& Society, 52, 301-320. https://doi.org/10.1080/10611932.2019.1693802

Yu, Y. 2019. Metaphorical representations of "leftover women": between traditional patriarchy and modern egalitarianism. - Social Semiotics, https://doi.org/10.1080/ 10350330.2019.1625515 